\title{
SIFAT FISIK DAN MEKANIK KOMPOSIT KAYU SEMEN-SERBUK GERGAJI
}

\section{Physical and Mechanical Properties of Sawdust- Cement Wood Composite}

\author{
Bakri, Endra Gunawan, Djamal Sanusi
}

This research aims to find out the effect of cement-saw dust ratio levels on the physical and mechanical properties of produced composites. The physical properties (density, water content, water absorption after the immersion of one hour and 24 hours, and thickness swelling after the immersion of one hour and 24 hours) and mechanical properties (MOE and MOR) were observed according to ISO standards. The results showed that the use of the cement to sawdust ratio of $3: 1$ in producing wood composite with the target density of $1200 \mathrm{~kg} / \mathrm{m}^{3}$ resulted in the lowest water absorption and the highest MOE and MOR. The swelling value and MOR of the produced boards were not acceptable, but their water content, water absorption, and MOE parameters were acceptable according to ISO 83351997.

Key Words : Physical and mechanical properties, cement wood composite, sawdust

\section{PENDAHULUAN}

Limbah kayu dapat dibagi menjadi dua golongan yaitu limbah eksploitasi dan limbah industri pengolahan kayu. Limbah industri pengolahan kayu terbesar berasal dari limbah industri penggergajian dan industri kayu lapis. Sanusi (1993) mendefinisikan limbah industri penggergajian sebagai bagian kayu yang dihasilkan dari proses penggergajian yang karena bentuk, ukuran dan cacat yang dimiliki tidak memungkinkan lagi dibuat sebagai sortimen kayu gergajian. Limbah industri pengolahan kayu dapat berupa serbuk gergaji (sawdust), sebetan (slabs), potongan-potongan (trims), dan serutan (skaring). Serbuk gergaji sebagai salah satu limbah industri penggergajian merupakan limbah yang dapat dimanfaatkan sebagai bahan bakar untuk sumber panas tanur, media jamur merang, bahan bakar industri batu bata/genteng, serta bahan baku untuk pembuatan papan mineral (papan semenserbuk gergaji).

Papan semen - serbuk gergaji adalah papan mineral yang bahan baku utamanya terdiri atas semen dan serbuk gergaji. Papan semen mempunyai kelebihan tertentu seperti tahan air, tahan kebakaran, dan tahan serangan serangga perusak kayu. Sifat papan semen dipengaruhi oleh berbagai faktor. Beberapa faktor yang menentukan sifat papan semen antara lain perbandingan (rasio) semen dengan partikel kayu, besarnya tekanan kempa, kerapatan papan, jenis mineral perekat (semen) yang digunakan, kadar air partikel kayu, dimensi (ukuran) partikel kayu dan pengeras atau katalisator (Prayitno, 1995).

Rasio semen dengan partikel kayu merupakan salah satu parameter penting yang mempengaruhi sifat papan semen yang dihasilkan.Penelitian ini dilaksanakan dengan tujuan untuk mengetahui pengaruh rasio antara semen dengan serbuk gergaji yang berasal dari limbah industri pengolahan kayu terhadap sifat fisik dan mekanik papan semen-serbuk gergaji.

\section{BAHAN DAN METODE}

\section{Persiapan Bahan Baku}

Bahan baku berupa serbuk gergaji dari campuran jenis kayu meranti putih, kelapa, dan jati terlebih dahulu diayak dengan ayakan 100 mesh untuk memisahkan serbuk gergaji dengan potongan kayu atau kotoran lain, sehingga diperoleh serbuk kayu yang berukuran hampir seragam dan bersih. Serbuk kemudian dikeringudarakan lalu disimpan dalam kantong plastik untuk kemudian dipersiapkan sebagai bahan pembuatan papan semen.

\section{Pembuatan Papan Semen}

Papan semen serbuk gergaji dibuat dengan target kerapatan $1.200 \mathrm{~kg} / \mathrm{m}^{3}$, sedangkan rasio semen dan serbuk gergaji adalah 2:1, 2,5:1, 3:1. Campuran semen dan serbuk gergaji dihitung dalam kondisi berat kering udara. 
Serbuk gergaji dan semen kering merek Bosowa tipe 1 yang telah ditentukan komposisinya kemudian dicampur dengan menggunakan alat pengaduk sehingga diperoleh campuran yang sempurna. Ke dalam campuran tersebut kemudian ditambah dengan air, sehingga diperoleh campuran basah. Campuran yang sudah siap tersebut dimasukkan ke dalam cetakan untuk pembuatan contoh uji. Lembaran papan basah yang sudah dicetak pada mal, dimasukkan ke dalam mesin kempa. Pengempaan dilakukan selama 8 jam, dengan target tebal $1,5 \mathrm{~cm}$. Lembaran papan yang telah dikempa, kemudian diklem selama 24 jam agar lembaran papan tetap kompak.

Lembaran papan yang telah selesai diklem kemudian dikeringudarakan pada rak yang telah disiapkan selama 28 hari. Lembaran papan yang telah mencapai kondisi kering udara kemudian disiapkan untuk pengujian.

\section{Penyiapan Contoh Uji dan Pengujian}

Penelitian ini dilaksanakan dengan menggunakan perlakuan 3 kali dan ulangan 3 kali, sehingga jumlah papan semen yang dibuat adalah 9 lembar. Lembaran papan yang telah dipersiapkan di atas, dipotong sesuai dengan ukuran contoh uji untuk pengujian sifat fisik dan mekanik. Pembagian lembaran papan dilakukan dengan menggunakan gergaji.

Parameter yang diuji adalah sifat fisik papan yang terdiri atas kerapatan, kadar air, penyerapan air setelah perendaman 1 dan 24 jam, dan pengembangan tebal, sementara sifat mekanik yang diuji terdiri atas keteguhan patah (MOR) dan modulus elastisitas. Pengujian sifat fisik dan mekanik tersebut dilakukan berdasarkan standar ISO 83351997.

\section{HASIL DAN PEMBAHASAN}

\section{Kerapatan}

Nilai kerapatan dari tiga jenis papan yang dibuat, terendah diperoleh pada papan dengan rasio semen-serbuk gergaji 2 :1 (Gambar 1). Rendahnya nilai kerapatan tersebut disebabkan karena ketebalan papan rata-rata yang dihasilkan melebihi target ketebalan papan yang diinginkan yaitu $1,5 \mathrm{~cm}$. Akibatnya volume papan menjadi lebih besar dibanding 2 jenis papan lainnya sehingga kerapatannya lebih rendah. Target tebal yang tidak tercapai tersebut disebabkan oleh rendahnya kadar semen sebagai pengikat partikel, sehingga meskipun diberi tekanan kempa yang cukup namun tetap tidak mampu mencapai target tebal yang ditetapkan.

Jika dibandingkan dengan nilai kerapatan papan semen berdasarkan standar ISO, maka nilai kerapatan papan semen dalam penelitian ini lebih tinggi dari kerapatan yang ditetapkan dalam standar yaitu sebesar $1000 \mathrm{~kg} / \mathrm{m}^{3}$.

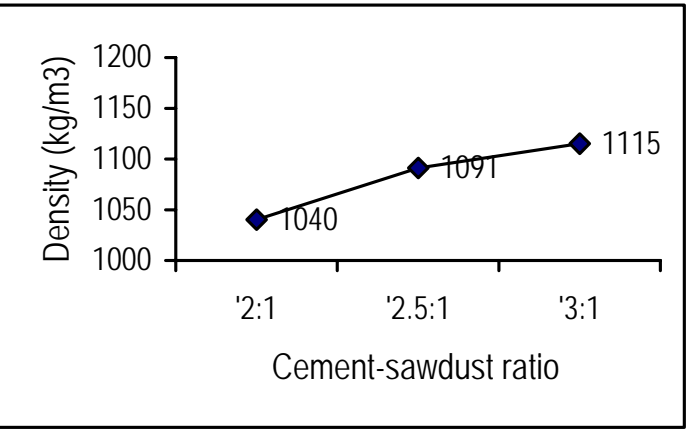

Figure 1. The effect of cement-saw dust ratio on the density of board

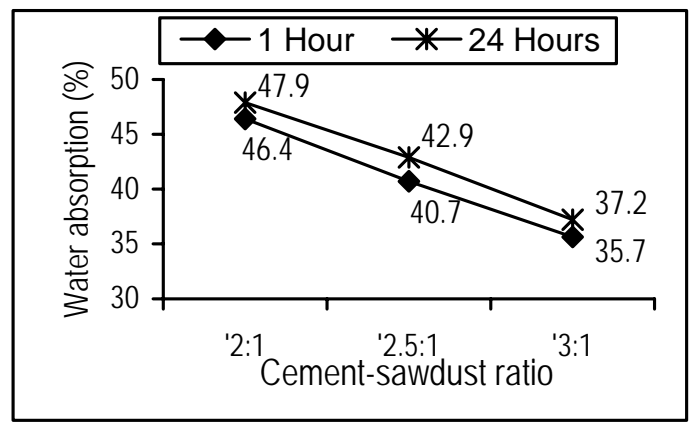

Figure 2. The effect of cement-saw dust ratio on the water absorption of board

\section{Penyerapan Air}

Penyerapan air terendah dihasilkan pada papan dengan rasio semen dan serbuk gergaji 3:1, sedangkan yang tertinggi pada rasio 2:1, baik setelah perendaman 1 jam maupun 24 jam (Gambar 2). Kecenderungan nilai penyerapan air yang diperoleh dalam penelitian ini sejalan dengan hasil penelitian Pfeister. (1985) yang menyatakan bahwa pada rasio semen dan serbuk gergaji yang tinggi (3:1), nilai penyerapan airnya lebih rendah dibandingkan rasio 2,0:1 dan 2,5:1. Rendahnya 
penyerapan air pada perlakuan rasio 3:1 disebabkan karena jumlah serbuk gergaji yang digunakan untuk membuat papan lebih sedikit dibandingkan perlakuan lainnya. Serbuk gergaji merupakan kayu dalam bentuk partikel yang bersifat higroskopis yaitu akan menyerap air jika kondisi lingkungannya lembab dan akan melepaskan air jika kondisi lingkungannya kering.

\section{Kadar Air}

Kadar air terendah diperoleh pada rasio semen dan serbuk gergaji 3:1 dan tertinggi pada rasio 2:1 (Gambar 3). Rendahnya kadar air tersebut disebabkan karena pada rasio 3:1, jumlah partikel serbuk gergaji lebih sedikit dibandingkan perlakuan lainnya. Selain itu proporsi semen yang lebih tinggi dapat mengisi ruang antar partikel serbuk gergaji secara rapat, sehingga serbuk gergaji tersebut sulit menyerap air, akibatnya kadar airnya lebih rendah. Jika dibandingkan dengan nilai kadar air papan semen berdasarkan standar ISO (6-12 \%), maka kadar air papan semen hasil penelitian ini lebih rendah.

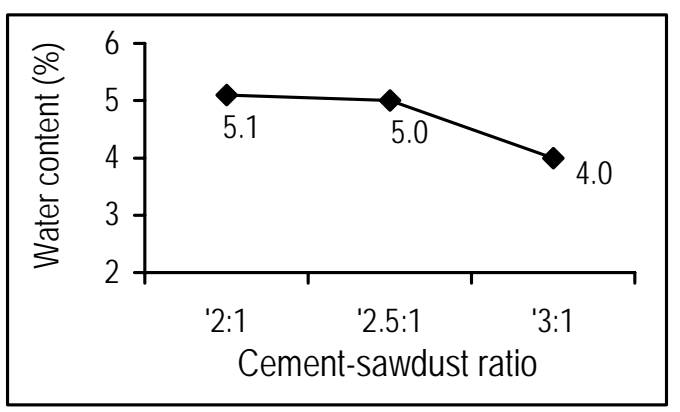

Figure 3. The effect of cement-saw dust ratio on the water content of board

\section{Pengembangan Tebal}

Pengembangan tebal terendah diperoleh pada rasio semen dan serbuk gergaji 3:1 dan tertinggi pada rasio 2,5:1, baik setelah perendaman 1 jam maupun 24 jam (Gambar 4). Tingginya pengembangan tebal pada rasio 2,5:1 diduga disebabkan proses pencampuran serbuk gergaji dengan semen tidak merata, sehingga partikel serbuk gergaji tidak tertutupi dengan rapat oleh partikel semen, akibatnya perlakuan 2,5:1 mengembang lebih tebal dibandingkan perlakuan lainnya.

Perlakuan 3:1 memberikan nilai pengembangan tebal yang paling kecil karena serbuk gergaji yang digunakan lebih sedikit dibandingkan perlakuan lainnya, sehingga nilai pengembangan dan penyusutannya juga lebih kecil. Selain itu proporsi jumlah semen yang lebih banyak menyebabkan tertutup partikel serbuk gergaji secara baik, sehingga serbuk gergaji tersebut sulit menyerap air yang menyebabkan papan sukar mengembang. Jika dibandingkan dengan nilai pengembangan tebal menurut standar ISO, maka nilai pengembangan tebal papan semen hasil penelitian ini lebih besar.

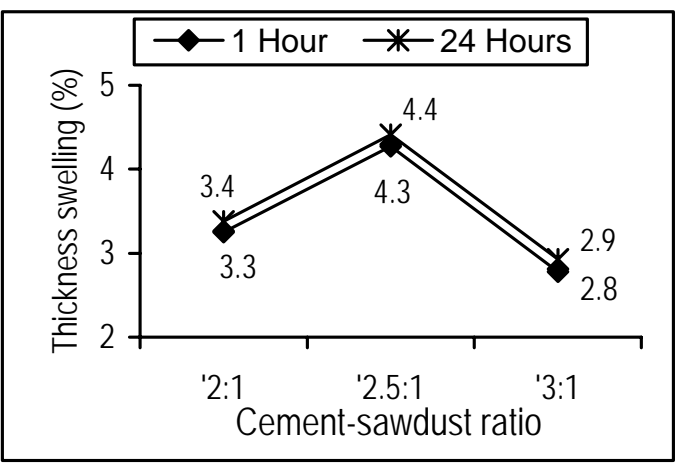

Figure 4. The effect of cement-saw dust ratio on the thickness swelling of board

\section{Modulus Elastisitas (MOE)}

Rasio semen dan serbuk gergaji 2:1 menghasilkan nilai MOE terendah, sedangkan nilai MOE tertinggi diperoleh pada rasio 3:1 (Gambar 5). Rasio 3:1 memberikan nilai MOE paling tinggi karena dengan rasio tersebut proporsi semen lebih tinggi, sehingga dihasilkan sifat papan yang lebih kaku dibandingkan dua jenis papan lainnyal. MOE merupakan suatu nilai yang menunjukkan sifat kekakuan suatu bahan. Jadi semakin tinggi nilai MOE suatu papan semen, maka papan tersebut akan semakin kaku. Jika dibandingkan dengan nilai MOE standar ISO( $3.000 \mathrm{~N} / \mathrm{m} \mathrm{m}^{2}$ ), maka nilai MOE papan hasil penelitian ini lebih tinggi.

\section{Keteguhan Patah (MOR)}

Hasil penelitian menunjukkan bahwa rasio semen dan serbuk gergaji 2:1 menghasilkan nilai MOR terendah, sementara nilai MOR tertinggi diperoleh pada papan dengan rasio semen dan serbuk gergaji 3:1 (Gambar 5). Hasil pengujian menunjukkan bahwa semakin tinggi rasio semen dengan serbuk gergaji, maka akan dihasilkan nilai 


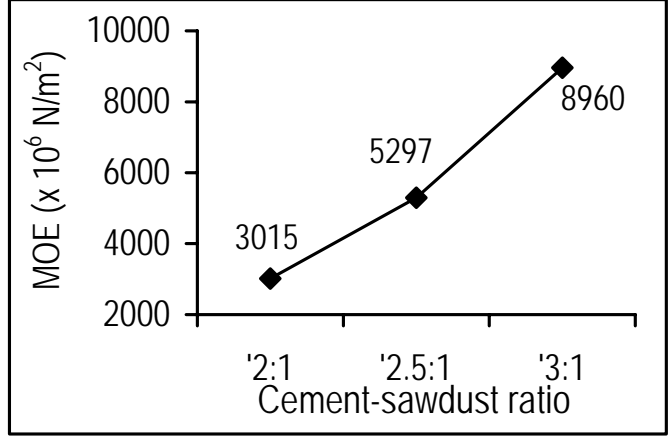

Figure 4. The effect of cement-saw dust ratio on the MOE of board

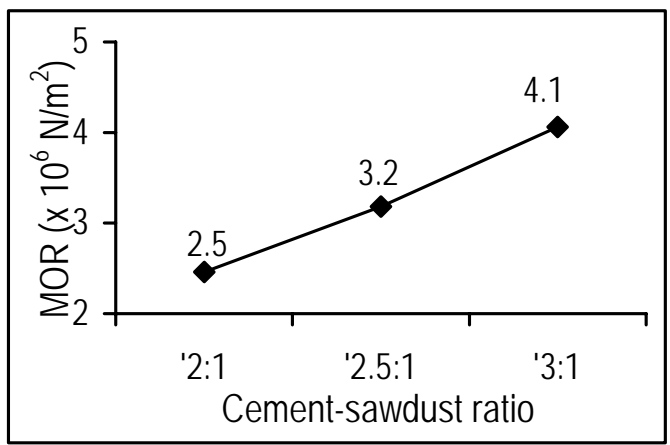

Figure 5. The effect of cement-saw dust ratio on the MOR of board

MOR yang semakin tinggi. Pada papan dengan rasio yang tinggi, maka proporsi semen yang digunakan untuk membuat papan lebih banyak dibandingkan proporsi serbuk gergaji. Papan yang mempunyai proporsi semen lebih banyak akan bersifat lebih kuat, sehingga kemampuan papan menahan beban akan lebih besar. Kondisi seperti ini akan menghasilkan papan yang mempunyai nilai MOR lebih besar. Jika dibandingkan dengan nilai MOR sesuai dengan standar ISO ( $>9 \mathrm{~N} / \mathrm{m}$ $\mathrm{m}^{2}$ ), maka nilai MOR papan semen hasil penelitian ini lebih kecil.

Diterima : 5 Januari 2006

Bakri dan Djamal Sanusi

Jurusan Kehutanan Universitas Hasanuddin

Kampus Unhas Tamalanrea, Makassar - 90245

Telp. (0411) 585917

Endra Gunawan

Alumni Program Magister, Pascasarjana

Universitas Hasanuddin

\section{KESIMPULAN}

Berdasarkan hasil pengujian beberapa sifat fisik dan mekanik papan semen serbuk gergaji, dapat disimpulkan bahwa limbah serbuk gergaji yang berasal dari industri pengolahan kayu dapat dimanfaatkan untuk bahan baku papan semen.

Hasil penelitian menunjukkan bahwa terdapat kecenderungan peningkatan sifat fisik dan mekanik papan semen dengan bertambahnya proporsi semen dalam pembuatan papan., Dalam penelitian ini, rasio semen dan serbuk gergaji yang menghasilkan papan dengan sifat-sifat terbaik adalah $3: 1$. Ditinjau dari nilai pengembangan tebal dan nilai MOR, papan hasil penelitian ini belum memenuhi standar ISO, sedangkan nilai kadar air, penyerapan air, dan MOE telah memenuhi standar ISO.

\section{DAFTAR PUSTAKA}

International Organisation for Standardisation, 1987. Cement bonded particleboard : Board of Portland of equivalent cement reinforced with fibrous wood. Reference number ISO 8335 International Organisation.

Pfeister C.S., 1985. The Influence of Cement/Wood Ratio and Cement Type on Bending Strength and Dimensional Stability of Wood-Cement Particleboard. Thesis Degree of Master of Science. University of Idaho.

Prayitno, T.A., 1995. Teknologi Papan Mineral. Fakultas Kehutanan Universitas Gadjah Mada. Yogyakarta.

Sanusi, Dj., 1993. Komposisi Limbah Industri Penggergajian dan Upaya Pemanfaatannya. Bulletin Penelitian UNHAS. Lembaga Penelitian Universitas Hasanuddin. Vol. VII. No. 23. 